\section{The Institute's primary Research Groups}

The coordinators of each of the Institute's four primary Research Groups report on their group's activities during the 1999/2000 academic year.

\section{The Environment and Culture Research Group Coordinator: Simon Hillson}

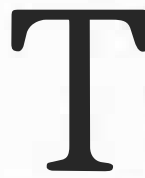
he Environment and Culture Research Group brings together the many staff and postgraduate research students whose research focuses on past interactions between people and the environments they have occupied. Since last year, it has been joined by the Institute's newly appointed lecturer in geoarchaeology, Arlene Rosen. Dr Rosen is a geoarchaeologist and phytolith analyst interested in the reconstruction of Holocene paleoenvironments, social responses to environmental change, and the development of agricultural systems. She is currently involved in field projects in Turkey, Israel and China.

\section{Research projects}

All the projects by members of the group mentioned in my report last year continue, and in addition the results of the long-term investigation by Gordon Hillman and colleagues of the beginnings of agriculture at Tell Abu Hureyra in Syria have been published. ${ }^{1}$ In this issue Martin Bridge describes (pp. 17-20) his dendrochronological research in England, Stephen Shennan outlines (pp. 21-23) the aims of a new research centre of which he is director and briefly describes one of its projects, Louise Martin discusses (pp. 39-42) her zooarchaeological research at Çatalhöyiik in Turkey, as does Dorian Fuller his archaeobotanical investigations in southern India (pp. 43-46), and Elizabeth Graham gives an account (pp. 52-56) of her work at the Maya site of Lamanai in Belize.

Two new projects involving members of thegroup were started during the past year. One is an investigation of human remains from Astypalaia, the westernmost of the Dodecanese Islands in Greece. In Classical times it was an independent state with its capital on the site of the present-day small town of Chora, where two large ancient cemeteries have recently been discovered - Kylindra and Katsalos. Kylindra dates to 600-400 BC and Katsalos spans a longer interval, from about $750 \mathrm{BC}$ to the Roman period. In 1999 the 22nd Ephorate of Prehistoric and Classical Antiquities, based on Rhodes, began the first rescue excavations at the cemeteries and invited the Institute to help recover, study and conserve the human remains, as a result of which I made two exploratory visits to Rhodes and Astypalaia. In the summer of 2001 I will take a team of specialists to Astypalaia. So far nearly 400 burials have been found, and the final total is estimated to be several thousand. The overall collection of remains is unique because the two cemeteries together appear to include all age cohorts of the population. Katsalos contains individuals ranging from babies to elderly adults, whereas Kylindra consists entirely of newborn babies, all buried in large pots. It is very unusual for ancient cemeteries to contain many burials of young children, but at Kylindra the large pots containing the burials have both protected the very delicate skeletons of the babies and acted as a marker that facilitated their discovery.

The second new project is also concerned with the study and conservation of human remains. It arose from the urgen situation in the Egyptian Delta, where accelerated development and land reclamation has led to the discovery of many cemetery sites of the Predynastic and early Dynastic periods, but changes in groundwater levels caused by irrigation are fast destroying the human remains. This situation is aggravated by a lack of trained personnel, facilities and funds in Egypt and the remains are frequently lost withou being studied. His Excellency Farouk Hosni, Egyptian Minister of Culture and President of the Supreme Council of Antiquities (SCA), together with its SecretaryGeneral Professor Gaballa A. Gaballa, have made strong appeals for help in the rescue of Delta sites. As a response, a workshop entitled "The bioarchaeological heritage of Egypt" was held during April 2000 in Qantara, North Sinai, hosted by the SCA and funded by the Wellcome Trust, UCL and the Bioanthropology Foundation, which resulted in the establishment of an international task force. The ultimate aim is to set up a series of climate-controlled stores and study centres, at which human remains can be conserved, stored and analyzed, and at which SCA personnel can be trained. The first is to be established at Qantara, with funding from the SCA and the Bioanthropology Foundation. We also hope to raise funds to enable specialists, with a mobile laboratory, to work alongside SCA archaeologists on the threatened sites in the Delta. The resulting collections will make possible fundamental research on changes in population and human health in relation to the origin of the ancient Egyptian state.

\section{Seminars}

Again this year the group followed its established practice of sponsoring two thematic series of seminars. Andrew Garrard organized the series in the autumn term entitled "Abrupt environmental change and its archaeological/historical impact". Two seminars focused on the Pleistocene. Clive Gamble (Southampton University) was justifiably cautious in relating the evolution and behaviour of pre-modern and early-modern humans to short-term climatic changes, whereas Gordon Hillman (UCL) made a strong case for the cold, dry interval in the terminal Pleistocene known as the Younger Dryas having triggered the beginnings of agriculture in Southwest Asia. Arlene Rosen (UCL) evaluated the impact of climatic fluctuations in the third millennium bc on societies in the Near East. Petra Dark (Reading University) related agrarian developments in Roman Britain to pollen-analytical evidence, and Mike Baillie (Queen's University Belfast) argued that the sudden climatic deterioration of AD 540 evident in the tree-ring record had devastating consequences and may have been caused by meteoritic impact.

"Genetics, demography and origins of farming in Europe" was the theme chosen for the spring-term seminars. Robin Allaby (UMIST) outlined the contribution of biomolecular evidence to the study of crop domestication, particularly in relation to maize and wheat. Stephen Shennan (UCL) summarized the results of his recently completed database project on the radiocarbon chronology of the Mesolithic/ Neolithic transition. Martin Richards (Huddersfield University) presented mitochondrial-DNA evidence for the origins of modern Europeans, and assessed the extent to which it may reflect Neolithic migration from western Asia. Marek Zvelebil (Sheffield University) outlined ways in which foragers and farmers may have interacted in Neolithic Europe and discussed their demographic, genetic and linguistic implications, and Brian Hayden (Simon Fraser University, Canada) presented a persuasive case for feasts having been a vital factor in social evolution and animal and plant domestication.

In addition to the main series, two other seminars were given by visitors: Melinda Zeder (Smithsonian Institution, Washington DC) discussed her recent re-analysis of archaeological data on goat domestication, and Hugo Yacobaccio (Universidad de Buenos Aires) described his research in the southern Andes, which has yielded new evidence on camelid domestication.

\section{Note}

1. A. M. T. Moore, G. C. Hillman, A. J. Legge, Village on the Euphrates: from foraging to farming at Abu Hureyra (New York: Oxford University Press, 2000). 


\section{The Social and Cultural Dynamics Research Group Co-ordinator: Ruth Whitehouse}

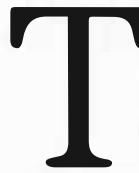

he Social and Cultural Dynamics Research Group brings together staff and postgraduate research students of the Institute whose primary interest is in anthropological and sociological approaches to the study of material culture. Its members share the common aim of studying the dynamics of material-culture systems, cutting across the regional and chronological boundaries that have traditionally divided archaeology.

\section{Research projects}

Several existing projects organized by members of the group continued and some new ones were initiated. The Faces Across the North Sea project on Viking art, which is part of the programme of collaboration between the Institute of Archaeology and the University of Science and Technology at Trondheim, continued. Its principal members at the Institute are James Graham-Campbell, Andrea Horne, Jeremy Tanner and Peter Ucko, and a productive meeting of all those involved was held at the Institute in September 2000. Kevin MacDonald continued his field research in West Africa (featured in AI 1997/98) and also started a new field project on the African diaspora in his home state of Louisiana, USA. Andrew Reid continued his work in East Africa (see pp. 35-38 in this issue), as did Vivek Nanda in India and Bill Sillar in Peru (both featured in $A I$ 1999/2000). Also in this issue (pp. 47-51) the Institute's recently appointed lecturer in Japanese archaeology, Koji Mizoguchi, describes his research on burial ritual and the centralization of power in Japan during the Yayoi period.

The archaeology of islands is a major research theme of the group, which currently includes four overseas field projects: Cyprian Broodbank's Kythera Island project (featured in AI 1999-2000), Todd Whitelaw's research at Knossos on Crete, Peter Drewett and José Oliver's work in the Caribbean (featured in AI 1997/98) and a new project started this year on Bali by Elisabeth Bacus. This year also saw the publication of a book by Cyprian Broodbank in which he presents the results of his research in the southern Aegean over the previous decade. ${ }^{1}$ Various aspects of island archaeology also figure in the work of several research students, reflecting the increasing importance of the subject in the spectrum of the Institute's research.

Another major focus of research by members of the group is on women in the past and in archaeology. For example, Katherine Wright has investigated the social customs of cooking and dining in Natufian and Pre-Pottery Neolithic settlements in Palestine and Jordan. ${ }^{2}$ In the autumn term she also organized the Insti- tute-wide research seminars held on the theme of "Women in antiquity", which ranged from Egypt and western Asia to West Africa, Mesoamerica and Peru. I continue to work on gender in Italian archaeology, as does Sue Hamilton. In September 2000 Sue organized a conference for the Sussex Archaeological Society on "Women's work: archaeology and the invisible sex". Pursuing this theme, the group is sponsoring a book, provisionally entitled Women in archaeology, women in antiquity (edited by Sue Hamilton, Ruth Whitehouse \& Karen Wright) based on the papers given at the Institute seminars and the Sussex conference. It will reflect current interest in the inter-related subjects of gender in the archaeological past and the role of women in the profession of archaeology, and will highlight the contributions being made by members of the Institute to this burgeoning field of study.

\section{Seminars, colloquia and workshops}

In addition to the group's contribution to the "Women in antiquity" seminars, it sponsored a series of South Asian colloquia during the spring term, organized by Vivek Nanda. The aim was to create a forum that focused on the art, archaeology, architecture and heritage of the Indian sub-continent. Each colloquium entailed one or more presentations on current research followed by discussion and a reception. The participants included visiting scholars as well as permanent members of the Institute; in particular they featured the Institute's four Charles Wallace Visiting Fellows from Bangladesh, India, Pakistan and Sri Lanka (see p. 3 of this issue). The colloquia included reports on major field projects as well as a range of wider research questions, including agricultural origins in South Asia, copper and bronze metallurgy, the Indian textile trade, maritime archaeology, and issues of art history and conservation.

In February 2001 the group joined with the Complex Societies Research Group and the UCL Departments of History and of Greek and Latin to hold a half-day seminar on a monumental new study of the history (and later prehistory) of the Mediterranean, inspired by the work of Fernand Braudel. ${ }^{3}$ The authors participated in the seminar, which was organized by Cyprian Broodbank and John Wilkes and included short presentations by Cyprian, Claudio Vita-Finzi, James Fentress and Michael Crawford. The occasion brought together archaeologists, anthropologists, ancient historians, geographers and historians in very lively and mutually profitable interaction.

As well as the seminars and colloquia sponsored by the group, a very interesting one-day workshop on the novel theme of "The archaeology of water: social and ritual dimensions" was held in April 2001, organized by a research student, Fay Stevens. Participants included Institute students and staff and members of the UCL Department of Anthropology and the University of Reading. The presentations encompassed springs, rivers, lakes, the sea, and even "water turned to stone" (stalagmites in cult caves), with examples drawn from Britain, Italy and the Americas and from the prehistoric to the recent past.

\section{Notes}

1. C. Broodbank, An island archaeology of the early Cyclades (Cambridge: Cambridge University Press, 2000).

2. K. L. Wright, "The social origins of cooking and dining in early villages of western Asia", Proceedings of the Prehistoric Society 66, 89-121, 2000.

3. P. Hordern \& N. Purcell, The corrupting sea: a stud y of Mediterranean history (Oxford: Blackwell, 2000). 


\section{The Complex Societies Research Group}

\section{Coordinator: Jon Hather}

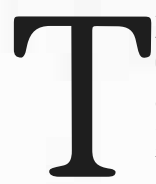

he Complex Societies Research Group is concerned with the archaeology of literate and proto-literate societies, and thus brings together the academic staff, honorary research staff and postgraduate research students of the Institute who work on the ancient civilizations of western Asia, Egypt, the Greek and Roman worlds, medieval Europe, India and Latin America. Its members maintain close links with the UCL Departments of History and of Greek and Latin, the British Museum, and the University of London's School of Oriental and African Studies, Institute of Classical Studies, Institute of Historical Research, Institute of Latin-American Studies and the London Centre for the Ancient Near East. The research undertaken by primary and secondary members of the group relates to three main themes: the economics of complex societies, urban landscapes, and language, art and religion.

\section{Research on the economics of complex societies}

Research is concerned with craft and industry, subsistence, and trade and exchange, and relates closely to research undertaken by members of the Environment and Culture primary group and the Material Culture and Technology secondary group. Clive Orton uses quantitative methods to analyze the organization of pottery production in Roman London and medieval Novgorod, and I investigate woodworking craft specialization at Novgorod and Roman Vindolanda. The technology of metal production in complex societies is a major focus, with work by Thilo Rehren on silver and lead in medieval Germany, steel production in early Islamic Uzbekistan, and silver mining in ancient Greece (see pp. 31-34 in this issue); by Dafydd Griffiths on steel making at early Islamic Merv in Turkmenistan (see AI 1999/2000); and by John Merkel on copper, silver and gold in pre-Inca Peru (see AI 1998/99). Thilo Rehren is also investigating glass-making in ancient Egypt. Delwen Samuel has continued her studies of food technology in ancient Egypt (see $A I$ 1999-2000), supported by a Wellcome Research Fellowship. Studies of trade and exchange are also a focus of interest, represented by Harriet Crawford's work at the Bronze Age settlement of Saar in Bahrain, which has demonstrated the existence of a previously unrecognized pattern of internal trade, ${ }^{1}$ and her new field project in Kuwait; Alan Johnston's research on Archaic and Classical Greek pottery; and Martin Welch's study of cross-Channel contacts between Franks and AngloSaxons in the sixth and seventh centuries $\mathrm{AD}$ (see pp. 28-30 in this issue).

\section{Research on urban landscapes}

A shared interest in the evolution of the social landscape of towns and cities is manifested in a wide range of fieldwork projects, for example that of Gustav Milne in London, John Wilkes at Sparta, David Jeffreys at Memphis, Georgina Herrmann at Merv, Ken Thomas in northwestern Pakistan, Vivek Nanda in southern India, and Bill Sillar at Raqchi in southern Peru (all of which have been featured in previous issues of $A I$ ). In addition, Kris Lockyear has recently started a field project at the Roman and Byzantine site of Noviodunum on the Danube in eastern Romania.

\section{Research on language, art and religion}

This third theme connects closely with the interests of the Social and Cultural Dynamics Research Group. The Celtic Inscribed Stones project (see AI 1998/99), a collaboration between the Institute and the UCL Department of History, has created an important database of inscriptions of the early Middle Ages from the Celtic areas of northwest Europe, of which the Breton corpus has already been published in English and French. ${ }^{2}$ James GrahamCampbell has also worked on the archaeology of death and wealth in the western Viking world. John Tait is studying texts from the Sacred Animal necropolis, North Saqqara, Egypt, to understand the administration of the necropolis and its cults, as well as demotic Egyptian texts (known as the Carlsberg Papyri) to explore the cultural and social traditions of the templecommunity of Tebtunis in the Fayum Oasis under Greek and Roman rule; and Harriet Crawford has begun a study of scribal practice and royal iconography in Mesopotamia.

\section{Seminars and conferences}

The group co-sponsors and participates in four continuing seminar series: medieval studies (with the British Museum's Department of Medieval and Modern Europe), Mycenaean and Classical archaeology (both with the Institute of Classical Studies) and Near Eastern archaeology (with the London Centre for the Ancient Near East).

In December 2000 the group sponsored a major international conference, "Encounters with Ancient Egypt", which examined how the cultures of Egypt - Predynastic, Dynastic, Hellenistic, Roman, Late Antique, Islamic and Colonial - have perpetually been re-configured in response to changing ideologies for appropriating the past. In a wide range of papers, new data as well as theoretical interpretations of familiar evidence were presented, and such was the success of the conference that the Institute has an agreement with a university press to publish a series of volumes arising from it. In February 2001 the group joined with the Social and Cultural Dynamics Research Group and the UCL Departments of History and of Greek and Latin to hold a half-day seminar to discuss, with the participation of the authors, The corrupting sea: a study of Mediterranean history (see p. 5 in this issue for a fuller description of this very interesting meeting).

\section{Notes}

1. See H. Crawford, Early Dilmun seals from Saar: art and commerce in Bronze Age Bahrain (Ludlow, Shropshire: LondonBahrain Archaeological Expedition, 2001).

2. W. Davies, J. Graham-Campbell, M. Handley, P. Kershaw, J. T. Koch, G. le Duc, K. Lockyear, The inscriptions of early medieval Brittany, Les inscriptions de la Bretagne du Haut Moyen Âge (Oakville, Connecticut and Aberystwyth, Wales: Celtic Studies Publications, 2000). 


\section{The Heritage Studies Research Group}

\section{Coordinator: Tim Schadla-Hall}

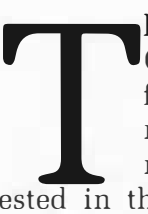

he Heritage Studies Research Group is the primary group for those staff, postgraduate research students and honorary research staff who are interested in the interpretation, presentation and conservation of what is usually referred to as the cultural heritage. Its members have strong theoretical as well as practical interests, and their expertise ranges from archaeological science to cultural landscapes, conservation and museum management. The main aim of the group is to facilitate and foster interdisciplinary research, through joint projects, workshops, lectures and seminars.

\section{Research projects}

This issue of $A I$ includes three articles by members of the group. Elizabeth Pye describes (pp. 24-27) her research on the techniques and designs used in Roman wall paintings, based mainly on her work at sites in England, Italy, Libya and Spain; Thilo Rehren writes (pp. 31-34) about his novel investigations of the ancient Greek and Roman mining installations that survive in southern Attica; and Sally MacDonald, Roy McKeown and Stephen Quirke explain (pp. 57-59) the initiatives they are taking to encourage greater access for research and teaching, via the Internet and in other ways, to the unique collections of the Petrie Museum of Egyptian Archaeology.

Other research by members of the group (much of which has been featured in previous issues of $A I$ ) continues, and new projects have been started. For example, Clifford Price's research collaboration with colleagues in Germany on salt damage in porous materials, such as stone, ceramics and wall paintings, has now produced a major European Commission report. ${ }^{1}$ The collaborative project on the excavation, conservation and presentation of the large urban site at Volubilis in Morocco, which was highlighted on the back cover of last year's $A I$, has made good progress. It is co-directed by Gaetano Palumbo, Visiting Professor Lisa Fentress and Moroccan colleagues, and two field seasons, in September 2000 and April 2001, have been undertaken (Fig. 1).

Closer to home, a major new interdisciplinary initiative is under way that involves three UCL departments: the Institute of Archaeology, the Bartlett School of Architecture, and the School of Library, Archive and Information Studies. They have come together to create at UCL a Centre for Historic Buildings, Collections and Sites to promote integrated research on the preservation and sustainable use of the material heritage.

\section{Seminars and lectures}

In October 2000 Dr B. R. Mani, (Superintending Archaeologist for Jamur and Kashmir, Archaeological Survey of India) gave a seminar on the rock art of Ladakh which dealt with the difficulties of ensuring the long-term conservation of rock art in the area, as well as providing insights into the meaning of the art. In March the annual Museum Studies Lecture was given by Charles Landry, founder and head of Comedia, one of Europe's foremost cultural planning consultancies. He has worked internationally on projects concerned with the revitalization of cities and has recently published a challenging book on the subject. ${ }^{2}$ In his lecture, entitled "Museums in the world of the experience economy", he suggested that museums should show greater confidence in promoting their role in contemporary society. He pointed out that many of the activities in which museums are involved have been used by the corporate sector for commercial and marketing purposes, and that museums could learn from that sector without compromising their own activities and at the same time play a vital role in urban society.

This year too, Nick Merriman, in his new capacity as CollegeCurator (see p. 3 in this issue), organized an inter-departmental meeting to discuss a new initiative being taken at UCL to create, next to the Bloomsbury Theatre, an arts and collections building, the Panopticon, that will house, among other facilities, the Petrie Museum of Egyptian Archaeology. Clive Orton, whose new book on sampling was recently published, ${ }^{3}$ has run several "data doctor" seminars at which research

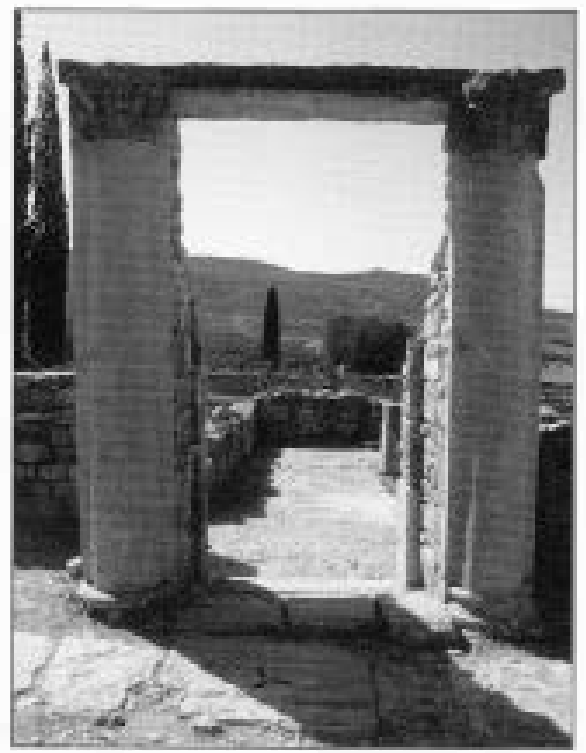

Figure 1 The restored entrance to the Roman "House of Orpheus" at Volubilis, Morocco. students and staff present for discussion quantitative problems that they have encountered in their research. And in May, the group sponsored a one-day meeting of the national Early Materials Forum that was held at the Institute. For further information about the meeting and about the aims of the forum see its website at www.ucl.ac.uk/archaeology/emf/.

\section{The Journal of Conservation and Museum Studies (JCMS)}

It is appropriate to conclude this report with a mention of JCMS, a web-based journal from the Institute of Archaeology that publishes student work in conservation and museum studies. It has been dormant for the past two years while the Institute's training programmes in conservation were being restructured, but is to be relaunched in the summer of 2001. It is not restricted to work undertaken at the Institute, and contributions from students of conservation and museum studies at any training institution around the world are welcomed. Full details of JCMS can be found on www.ucl.ac.uk/archaeology/ conservation/jcms/.

\section{Notes}

1. C. A. Price (ed.), An expert chemical model for determining the environmental conditions needed to prevent salt damage in porous materials. European Commission, Protection and Conservation of the European Cultural Heritage, Research Report 11 (London: Archetype, 2000).

2. C. Landry, The creative city: a toolkit for urban innovators (London: Earthscan, 2000).

3. C. R. Orton, Sampling in archaeology (Cambridge: Cambridge University Press, 2000). 


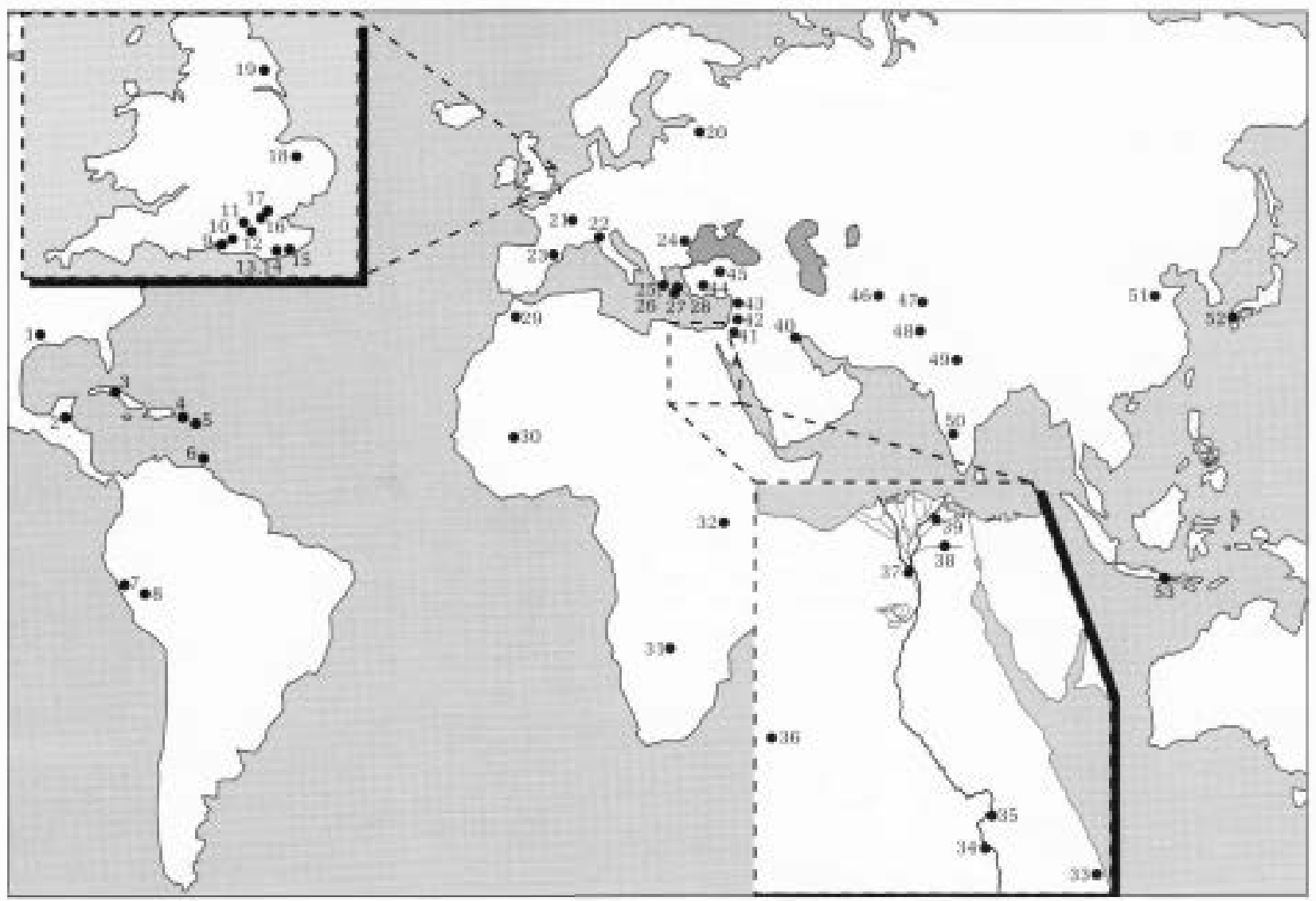

North and South America

1. Cane River, Louisiana, USA

MacDonald: historic (creole)

2. Lamanai, Belize

Graham: multiperiod

3. Los Buchillones, Cuba Graham: 12 th-17th cen tury $A D$

4. Caguana, Puerto Rico Oliver: Prehispanic

5. Tortola, Virgin Islands Drewett: Prehispanic

6. Barbados

Drewett: Prehispanic

7. Batan Grande, Peru Merkel: Prehispanic (Sican)

8. Raqchi, Peru Sillar (multiperiod)

\section{World distribution of current field projects}

\section{England}

9. Boxgrove, Sussex Roberts: Palaeolithic

10. Bignor, Sussex Rudling: Roman

11. Barcombe, Sussex Rudling: medieval

12. Mount Caburn, Sussex Drewett, Hamilton: multiperiod

13. Winchelsea, Sussex D. Martin: medieval

14. Cinque Ports coastal survey, Kent, Sussex Clarke, Milne: Romanmedieval

15. Lydd, Kent Barber: medieval

16. Ewell, Surrey Orton: Roman

17. Thames foreshore, London

Milne: medieval-present

18. Sedgef ord, Norfolk Faulkner: multiperiod

19. Pickering, Yorkshire Schadla-Hall: Mesolithic

Continental Europe

20. Novgorod, Russia

21. Burgundy, France Hamilton: Iron Age

22. Eastern Po Plain, Italy Whitehouse: Bronze Age, Roman

23. Empordà, Spain McGlade: multiperiod

24. Noviodunum, Romania Lockyear: RomanByzantine

25. Kythera, Greece Broodbank, Conolly: multiperiod

26. Lavrion, Greece Rehren: Classical

27. Knossos, Greece Whitelaw: multiperiod

28. Astypalaia, Greece Hillson: ArchaicClassical
Africa

29. Volubilis, Morocco Fentress, Palumbo: Islamic

30. Inland Niger Delta, Mali MacDonald: Pre-Islamic

31. Dikalate, Botswana Reid: Iron Age

32. Buganda, Uganda Reid: Iron Age-historic

33. Wadi Gimal, Egypt Hassan: multiperiod

34. Hierakonpolis, Egypt Adams: Predynastic

35. Thebes, Egypt Janssen: Dynastic

36. Farafra Oasis, Egypt Hassan: Palaeolithic

37. Memphis, Egypt Jeffreys: multiperiod

38. Kafr Hassan Dawood, Egypt

Hassan: multiperiod

39. Qantir-Piramesses, Egyp Rehren: Bronze Age
Asia

40. as-Sabiyah, Kuwait Carter, Crawford: Neolithic

41. Wadi Faynan, Jordan Wright: Bronze Age

42. Wadi Zarka, Jordan Palumbo: multiperiod

43. Sidon, Lebanon Doumet, Griffiths: multiperiod

44. Çatalhöyiik, Turkey L. Martin, Rosen: Neolithic 45. Paphlagonia, Turkey Matthews: multiperiod

46. Merv, Turkmenistan Herrmann: multiperiod

47. Akhsiket, Uzbekistan Rehren: Islamic

48. Bannu, Pakistan Thomas: multiperiod

49. Garhwal, India Fuller: Early Historic

50. Karnataka, India Fuller: Neolithic

51. Yiluo River, China Rosen: Neolithic-Bronze Age

52. Matsumotu, Japan Mizoguchi: 1st century BC (Yayoi)

53. Bali, Indonesia Bacus: multiperiod

- The list includes only the projects involving survey or excavation (or both) run by members of the Institute or to which they make a major contribution (indi vidual research students' field rojects are excluded, as are study visits to museum and other collections). and only the main members of the Institute involved in each project are named; staff from other UCL departments and other UK and overseas universities and organizations also participate in many of the projects and in some cases co-direct them.

- All the overseas projects depend on collaboration with local archaeologists and with the relevant antiquities services, museums or universities, and several of them also involve collaboration with other UK universities, colleges, museums and other organizations, e.g.9 (English Heritage, Natural History Museum), 19 (Cambridge, Durham), 20 (Bournemouth), 24 (Southampton), 25 (Cambridge, Oxford, Sheffield), 37 (Egypt Exploration Society), 41 (Leicester), 43 (British Museum). 44 (Cambridge), 48 (British Museum). 